\title{
Statistically based approach to select worst-case groundwater scenarios for environmental risk assessment of pesticides in Brazil
}

\author{
Scorza Júnior, R.P. ${ }^{1,2,}$, CAnesin, F.H. ${ }^{2}$; Seabra, F.A.S. ${ }^{2} \&$ Comunello, E. ${ }^{1}$ \\ ${ }^{1}$ Embrapa Agropecuária Oeste, Dourados, Mato Grosso do Sul, Brasil. \\ ${ }^{2}$ Programa de Pós-Graduação em Recursos Naturais, Universidade Estadual de Mato Grosso do Sul (UEMS), Dourados, MS.
}

Received October 10, 2018; Accept December 26, 2018

\begin{abstract}
Exposure scenarios in combination with simulation models have been used in the procedure of Environmental Risk Assessment (ERA) of pesticides to estimate exposure concentrations in environmental compartments. The appropriate definition of exposure scenarios is primordial to guarantee ERA purpose to evaluate if a pesticide use in an intended area can be considered safe. This work had the aim to present and test a geo- and statistically based approach to define worst-case groundwater exposure scenarios for Brazil. To do so, soil-climate data of Mato Grosso do Sul state consisting of 42 locations (3 soil classes and 14 meteorological stations) were used to generate populations of Predicted Environmental Concentrations (PEC) at 3 and 5 -m depth for a simulation period of 24 years. A total of 3,780 graphs were generated of PEC populations for 15 "dummy" pesticides. After setting equal risks in both dimensions (spatial and temporal) equal to $20 \%$, the overall risks exceedance of tested worst-case groundwater exposure scenarios were about $10 \%$ for both depths. Thus, this approach can be considered suitable to guarantee a pre-defined overall risk exceedance once defined by the regulatory authorities in Brazil.
\end{abstract}

Keywords:Environmental risk assessment. Exposure assessment. Exposure scenario.Pesticide.

\section{INTRODUCTION}

Exposure assessment to non-target organisms is an important aspect of the Environmental Risk Assessment (ERA) of pesticides, which has been carried out by using simulation models and associated exposure scenarios to generate Predicted Environmental Concentrations (PEC) in different compartments (i.e. soil, water, air etc). These simulation models represent the main exposure routes of contamination (i.e. surface runoff, spray drift, leaching etc) and processes of pesticide fate in the environment.

Exposure scenarios are created by taking into account the diversity of soil types, climate conditions, crops and soil management for the intended area of pesticide use (FOCUS, 2000 ) and should represent, in the first tiers, realistic worstcase situations regarding vulnerability of soil and climate conditions. However, due to continental dimension of Brazil leading to an enormous diversity of soil types and climate conditions, it is very likely that only one worst-case scenario for groundwater or surface water cannot be applied for the whole country in the ERA of pesticides. To overcome this limitation, one possibility to increase representativeness and to be more realistic is to divide Brazil in some regulatory zones based on, for example, similarities of climate conditions, soil types and crop cultivation. There is a tendency to consider more relevant in the ERA of pesticides the differences of environmental conditions for exposure scenario definition rather than the complexity level of simulation models for regulatory purpose. Simulation models for regulatory purpose are already well developed but more representativeness, less simplification of reality and more ecological realism are necessary in the ERA of pesticides.

To guarantee realistic worst-case situation, an adequate spatial analysis of soil and climate conditions should be carried out and ideally considering as cientific-based and statistically approach in the scenario selection. In Brazil, attempts have

*Corresponding author: Rômulo Penna Scorza Júnior; e-mail: romulo.scorza@embrapa.br 
been done to characterize the vulnerability of groundwater to pesticide contamination (Hirata et al., 1997; Scorza Júnior\& Silva, 2007). More recently, Mingoti et al. (2016) presented an index to characterize the vulnerability of Brazilian groundwater to pesticide contamination in the Cerrado biome. These studies of groundwater vulnerability to pesticides can be an initial step in the development of exposure scenarios. However, none of them had the aim to take into consideration a pre-defined risk exceedance approach. On the other hand, Bach et al. (2016) proposed an approach that considers full spatio-temporal distribution of PEC values in the intended area of pesticide use. Moreover, this approach allows scenario selection based on pre-defined overall percentile of concentration risk exceedance (i.e. combination of spatio and temporal percentiles of concentration risk exceedance) that needs to be defined by the regulatory authority.The main advantage of this approach is to allow authorities to derive exposure endpoints based on level of protection or risk exceedance within the intended area of pesticide use. Therefore, it is clear for all stakeholders the level of protection considered in the ERA of pesticide. One disadvantage of this approach can be the computational time required due to a great amount of data if considering all combinations of soil types, climate conditions and pesticides for a region.

In the European Union (EU), the definition of exposure scenarios used for ERA of pesticides for surface and groundwater was based on expert judgment more than using statistically based approaches (Bach et al., 2016). However, some member states as Germany are developing their national ERA of pesticides and exposure scenarios using statistically based approaches that consider more robust and refined spatial data analysis. In the USA, the Environmental Protection Agency (EPA) has recently proposed six regional andcropspecific exposure scenarios for groundwater to better represent the diversity of soil and climate conditions in the country (USEPA, 2015). Although EPA states that these six scenarios should represent vulnerable locations based on groundwater depth, leaching potential and persistence of pesticides, it is not clear if a systematic and statistically-based approach has been used in the scenario definition. In Brazil, ERA of pesticides for surface and groundwater has been partially carried out by authorities since 2011 as only first tiers are considered (Rebelo $\&$ Caldas, 2014). However, more recently a working group has been created to propose new procedures for surface water (e.g. definition of worst-case exposure scenarios, simulation models for exposure assessment etc).

This work had the aim to present in a systematic way a scientifically based approach to define worst-case groundwater exposure scenarios in Brazil using soil and climate data of Mato Grosso do Sul State. This approach is based on the work of Bach et al. (2016) and has not been tested for definition of worst-case exposure scenarios in Brazil until now. Moreover, this approach can be used to develop Brazilian specific soilclimate exposure scenarios and to define overall percentilebased exposure endpoints within ERA of pesticides at different Brazilian agricultural areas of pesticide use.

\section{MATERIALS AND METHODS}

The meteorological data used as input for simulations of pesticide leaching were: i) daily precipitation; ii) daily maximum and minimum air temperatures; and iii) daily potential evapotranspiration. Daily precipitation data of Mato Grosso do Sul between 1912 and 2013 weregathered from 520 meteorological stations using HidroWeb database (ANA, 2018). Daily maximum and minimum air temperatures, wind velocity at 2-m height, relative air humidity and global solar radiation were obtained from POWER - Prediction of Worldwide Energy Resource database (Stackhouse et al., 2015). Daily potential evapotranspiration was estimated using Penman-Monteith equation (Allen et al., 1998). One limitation of POWER database is the availability of data only after June 1983 for Mato Grosso do Sul state. Because of that, we defined the simulation period between June 1983 and August 2013 (i.e. 30 years). Within this period between June 1983 and August 2013, we obtained 163 meteorological stations that were reduced to 14 after applying the following criteria: i) at least 30 years of daily precipitation time-series; ii) less than $5 \%$ of failure or missed data in the time-series; iii) located within the intended area of pesticide use in Mato Grosso do Sul state.The spatial distribution, geographical coordinates, mean annual accumulated precipitation and mean annual air temperature for all 14 meteorological stations are shown in Figure 1 and Table 1.

The source for soil classification was the soil map (1: 1.500.000) of Mato Grosso do Sul State (MATO GROSSO DO SUL, 1990) (Figure 1). Soil representativeness was based on distribution of each soil class within $50-\mathrm{km}$ perimeter of each 14 meteorological stations (Table 2). The three soil classes selected and the range of occupied area within each $50-\mathrm{km}$ perimeter of all 14 meteorological stations were: i) Red-Yellow Argisol (1-33\%); ii) Red Latosol (21-99\%) and iii) Quartzarenic Neosol (0.3-77\%). At the end, 42 soilclimate scenarios or locations were used in the simulations (3 soil classes x 14 meteorological stations).

We used the one-dimensional, physically based pesticideleaching model FOCUS PEARL version 4.4.4 (Vanden Berg et al., 2016) to simulate the predicted environmental concentrations (PEC) for all 42 soil-climate scenarios. Input parameters for all three soil classes (Table 3 ) were based on Scorza Júnior \& Silva (2007). The soil profile was divided into eight layers $(0-10,10-20,20-40,40-60,60-100,100-150,150$ 200 and 200-600 cm depth) and the van Genuchten parameters were derived from site-specific laboratory experiments using the RETC package (van Genuchtenet al., 1991). The lower boundary condition assumed for all simulations was free drainage of soil profile. The PECs were given as annual average concentrations of pesticide at 3 and 5-m depth. FOCUS PEARL is a one-dimensional and physically based model that describes the transport of pesticides in the soil liquid phase (i.e. leaching) using the convection-dispersion equation. Moreover, it considers pesticide degradation by first-order kinetics, sorption by Freundlich model, uptake by plant roots, pesticide 


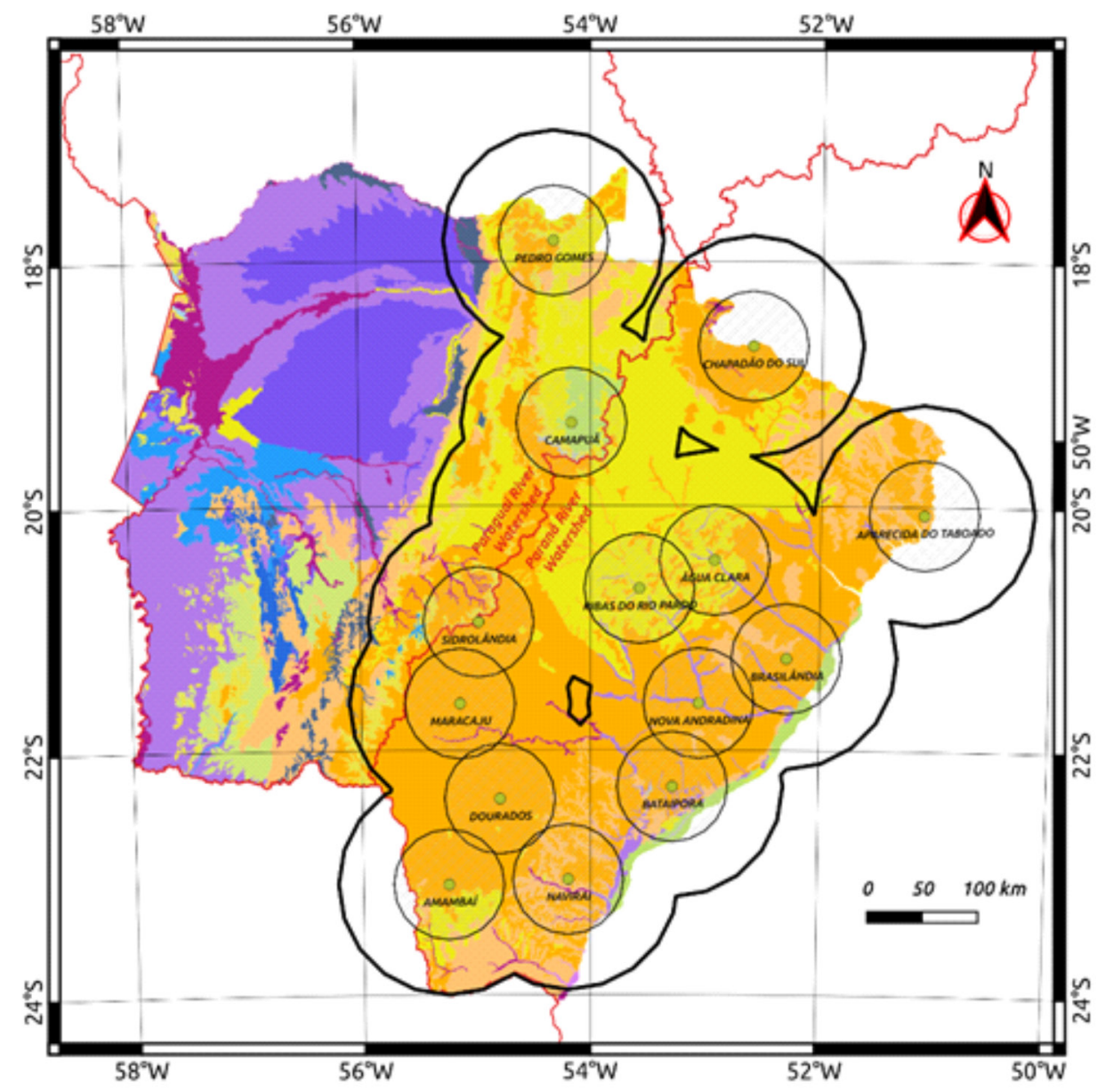

\section{LEGEND}

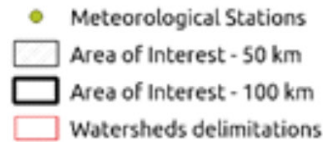

Soil Classes

Red-Yellow Argisol
Red Latosol
Red Nitosol
Argilluvic Chernosol
Rendzic Chernosol
Espodosol
Cleysol
Organosol
Haplic Planosol
Plinthosol
Vertisol
Fluvic Neosol
Litholic Neosol
Quatzarenic Neosol
Regolichic Neosol
Soils association
Sand Bank
Water Bodies
No Classification

Figure 1. Spatial distribution of 14 meteorological stations and soil types in Mato Grosso do Sul Sate.

volatilization and others. FOCUS PEARL model has been used to support authorities in decisions concerning the approval of pesticide registration in the European Union (FOCUS, 2000).

An overview of the procedure to select the worst-case groundwater scenarios is shown in Figure 2. After definition of local combinations of soil-climate scenarios (42 combinations in our study), there is a need to defined some generic or "dummy" pesticides. Ideally, these pesticides should cover some range of persistence and retention characteristics, represented by the half-life (i.e. DT50) and the organic carbon sorption coefficient (i.e. $\mathrm{K}_{\mathrm{OC}}$ ), respectively.Three different DT50 values (i.e. 3,30 and 300 days) and five different $\mathrm{K}_{\mathrm{OC}}$ values (i.e. 10, 100, 1000, 10000 and $100000 \mathrm{~L} \mathrm{~kg}^{-1}$ ) were used for simulations to represent the range of pesticides. Besides pesticide persistence and retention characteristics, we also varied some scenario features as pesticide application date. Pesticide was applied only one time per month and during 10 consecutive months (starting from September till June). Application dates were fixed within each month that resulted in a 30-day interval among each application. The rationale of pesticide application period between September till June was to mimic the crop sequence soybean-corn, which is the main crop system in Mato Grosso do Sul state, and also to consider the main period of the year when pesticides are used.
The total number of simulations was 3.780 for the two output depths (i.e. 3 and $5 \mathrm{~m}$ ), as the combination result of 15 generic pesticides, 42 soil-climate scenarios and 3 different pesticide application dates. For each output depth, 1890 time series of 24 years were obtained that resulted in space and time PEC population for each generic pesticide. A warm-up period of six years was considered for each 30-year simulation to allow model stabilization and to avoid systematic deviations in the time series (Vanderborght et al., 2011). So, only PEC values of 24 years were used in the analysis. The next step was to rank the 42 soil-climate scenarios using as the criteria the fifth highest annual average concentration of pesticide in time. It is important to notice that the fifth highest value of the annual average concentration of pesticide represent 80th percentile in time. After ranking the 42 soil-climate scenarios, all 24 PEC values of annual average concentration of pesticide within each location were ranked in a descending order. At the end, a 3-D graph was generated with locations, years and PEC values of annual average concentration of each pesticide. In this approach, we defined that risk exceedance of threshold concentration would be $20 \%$ for both dimensions (i.e. 80 th percentile in time and space). This definition of $20 \%$ risk exceedance was used an example to illustrate this approach and should be defined by the regulatory authorities. The 
Table 1. Geographical coordinates, mean annual precipitation $(\mathrm{mm})$ and mean annual air temperature $\left({ }^{\circ} \mathrm{C}\right)$ of all 14 meteorological stations.

\begin{tabular}{|c|c|c|c|}
\hline Location & $\begin{array}{l}\text { Geographical } \\
\text { coordinates }\end{array}$ & $\begin{array}{c}\text { Mean annual } \\
\text { precipitation } \\
(\mathrm{mm})\end{array}$ & $\begin{array}{c}\text { Mean } \\
\text { annual air } \\
\text { temperature } \\
\left({ }^{\circ} \mathrm{C}\right)\end{array}$ \\
\hline Amambai & $\begin{array}{l}23^{\circ} 05^{\prime} 52.1^{\prime \prime} \mathrm{S} \\
55^{\circ} 14^{\prime} 37.0^{\prime \prime} \mathrm{W}\end{array}$ & 1909 & 24.5 \\
\hline $\begin{array}{l}\text { Aparecida do } \\
\text { Taboado }\end{array}$ & $\begin{array}{l}20^{\circ} 04^{\prime} 05.9 ” \mathrm{~S} \\
51^{\circ} 06^{\prime} 13.0 ” \mathrm{~W}\end{array}$ & 1203 & 27.7 \\
\hline Bataiporã & $\begin{array}{l}22^{\circ} 17^{\prime} 55.0^{\prime \prime} \mathrm{S} \\
53^{\circ} 16^{\prime} 49.1^{\prime \prime} \mathrm{W}\end{array}$ & 1365 & 24.1 \\
\hline Brasilândia & $\begin{array}{l}21^{\circ} 14^{\prime} 57.8^{\prime \prime} \mathrm{S} \\
52^{\circ} 17^{\prime} 17.2^{\prime \prime} \mathrm{W}\end{array}$ & 1248 & 24.3 \\
\hline Camapuã & $\begin{array}{l}19^{\circ} 19^{\prime} 19.9^{\prime \prime} \mathrm{S} \\
54^{\circ} 09^{\prime} 40.0 ” \mathrm{~W}\end{array}$ & 1212 & 24.2 \\
\hline $\begin{array}{l}\text { Chapadão do } \\
\text { Sul }\end{array}$ & $\begin{array}{l}18^{\circ} 41^{\prime} 30.1^{\prime \prime} \mathrm{S} \\
52^{\circ} 35^{\prime} 38.0 ” \mathrm{~W}\end{array}$ & 1826 & 24.1 \\
\hline Dourados & $\begin{array}{l}22^{\circ} 23^{\prime} 53.2^{\prime \prime} \mathrm{S} \\
54^{\circ} 47^{\prime} 30.1^{\prime \prime} \mathrm{W}\end{array}$ & 1381 & 23.9 \\
\hline Maracaju & $\begin{array}{l}21^{\circ} 37^{\prime} 07.0^{\prime \prime} \mathrm{S} \\
55^{\circ} 08^{\prime} 12.8^{\prime \prime} \mathrm{W}\end{array}$ & 1317 & 24.3 \\
\hline Naviraí & $\begin{array}{l}23^{\circ} 03^{\prime} 28.1^{\prime \prime} \mathrm{S} \\
54^{\circ} 11^{\prime} 38.0^{\prime \prime} \mathrm{W}\end{array}$ & 1435 & 23.6 \\
\hline $\begin{array}{l}\text { Nova } \\
\text { Andradina }\end{array}$ & $\begin{array}{l}21^{\circ} 36^{\prime} 55.1^{\prime \prime} \mathrm{S} \\
53^{\circ} 03^{\prime} 07.9^{\prime \prime} \mathrm{W}\end{array}$ & 1575 & 24.1 \\
\hline Pedro Gomes & $\begin{array}{l}17^{\circ} 49^{\prime} 50.9^{\prime \prime} \mathrm{S} \\
54^{\circ} 18^{\prime} 47.2^{\prime \prime} \mathrm{W}\end{array}$ & 1521 & 24.6 \\
\hline Água Clara & $\begin{array}{l}20^{\circ} 26^{\prime} 43.1^{\prime \prime} \mathrm{S} \\
52^{\circ} 55^{\prime} 08.0^{\prime \prime} \mathrm{W}\end{array}$ & 1358 & 24.5 \\
\hline $\begin{array}{l}\text { Ribas do Rio } \\
\text { Pardo }\end{array}$ & $\begin{array}{l}20^{\circ} 40^{\prime} 36.8^{\prime \prime} \mathrm{S} \\
53^{\circ} 34^{\prime} 17.0^{\prime \prime} \mathrm{W}\end{array}$ & 1273 & 24.2 \\
\hline Sidrolândia & $\begin{array}{l}20^{\circ} 57^{\prime} 05.0^{\prime \prime} \mathrm{S} \\
54^{\circ} 58^{\prime} 18.1^{\prime \prime} \mathrm{W}\end{array}$ & 1390 & 24.2 \\
\hline
\end{tabular}

combination of risk exceedance for both dimensions will lead to an overall risk exceedance that can be easily derived from the 3-D graph.

\section{RESULTS AND DISCUSSION}

The 42 soil-climate scenarios covers an area of about 105 $083 \mathrm{~km}^{2}$, which corresponds to $62 \%$ of the Paraná watershed in Mato Grosso do Sul (Figure 1). The agricultural land in Mato Grosso do Sul State is mainly at Paraná watershed and this corresponds to the area where pesticides are potentially used. Thus, these scenarios covers about $62 \%$ of the area where pesticides are potentially used in Mato Grosso do Sul State. Although there is no recommendation of how representative this should be, we do believe that covering $62 \%$ of the area where pesticides are potentially used is sufficient to guarantee
Table 2. Soil classes distribution for each location ( $\%$ of area within the $50-\mathrm{km}$ perimeter). The numbers within parentheses are the total area of each soil-climate scenario within the area where pesticides are potentially used in Mato Grosso do Sul State.

\begin{tabular}{lccc}
\hline & \multicolumn{3}{c}{ Soil classes } \\
\cline { 2 - 4 } Location & $\begin{array}{c}\text { Red-Yellow } \\
\text { Argisol }\end{array}$ & Red Latosol & Quartzarenic Neosol \\
\hline Amambai & $5.8(0.27)$ & $60.5(2.76)$ & $24.2(1.10)$ \\
Aparecida & $14.9(0.68)$ & $31.4(1.43)$ & $\mathrm{NP}$ \\
do Taboado & & & \\
Bataiporã & $9.4(0.43)$ & $64.3(2.93)$ & $1.6(0.07)$ \\
Brasilândia & $8.7(0.39)$ & $72.1(3.29)$ & $\mathrm{NP}$ \\
Camapuã & $\mathrm{NP}$ & $25.9(1.18)$ & $35.2(1.60)$ \\
Chapadão do & $\mathrm{NP}$ & $47.2(2.16)$ & $2.1(0.10)$ \\
Sul & & & $0.3(0.01)$ \\
Dourados & $1.0(0.05)$ & $98.7(4.50)$ & $\mathrm{NP}$ \\
Maracaju & $\mathrm{NP}$ & $98.7(4.50)$ & $0.5(0.02)$ \\
Naviraí & $33.1(1.51)$ & $57.5(2.62)$ & $\mathrm{NP}$ \\
Nova & $5.5(0.25)$ & $86.6(3.95)$ & $37.8(1.72)$ \\
Andradina & & & $54.0(2.46)$ \\
Pedro & $10.2(0.47)$ & $28.3(1.29)$ & $76.5(3.48)$ \\
Gomes & & & $0.9(0.04)$ \\
Água Clara & $2.1(0.09)$ & $40.8(1.86)$ & \\
Ribas do Rio & $\mathrm{NP}$ & $21.4(0.98)$ & \\
Pardo & & $88.7(4.04)$ & \\
Sidrolândia & $\mathrm{NP}$ & & \\
NP= not present & & & \\
& & &
\end{tabular}

representativeness. The area of each soil-climate specific scenarios within the area of potential use of pesticides ranged from 0.01 to $4.50 \%$ (Table 2).

A total of 3780 graphs of spatio-temporal PEC distribution were built based on the procedure described above. These 3780 graphs are the result of the following combination: 15 generic pesticides x 42 soil-climate scenarios $\times 3$ pesticide application dates $\mathrm{x} 2$ output depths. However, to illustrate the approach, only two examples using contrasting pesticides are shown in Figures 3 and 4. These results can be extrapolated to real pesticides by the similarity of persistence (i.e. DT50) and retention (i.e. $\mathrm{K}_{\mathrm{OC}}$ ) characteristics. By doing so, we assume that PEC population for the real and "dummy" pesticides in space and time is the same. The main advantage of this assumption is to avoid running simulations for all scenarios every time a pesticide needs to be assessed. Besides DT50 and $\mathrm{K}_{\mathrm{OC}}$, some other pesticide parameters can influence leaching of pesticides. However, pesticide-leaching models are more sensitive to parameters related to persistence and retention (Boesten, 1991; Dubus \& Brown, 2002).

The PEC population of average annual concentration at 3-m depth for a pesticide with DT50 and $\mathrm{K}_{\mathrm{OC}}$ about 30 days and $58 \mathrm{~L} \mathrm{~kg}^{-1}$, respectively, is shown in Figure 3. For this specific pesticide, PEC values within the population ranged from 0 to $101 \mu \mathrm{g} \mathrm{L}^{-1}$. After ranking all 42 locations based on 80 th percentile in time (i.e. the fifth highest value of the annual average concentration), we identified that location 42 corresponds to the 80 th percentile in space. This can be 
Table 3. Soil input parameters for all soil used in simulations. $\mathrm{OM}=$ organic matter content; $\mathrm{BD}=$ dry soil bulk density; $\theta_{\mathrm{r}}=$ residual volumetric water content; $\theta_{\mathrm{S}}=$ saturated volumetric water content; $\alpha, \mathrm{n}$ and $\lambda$ are van Genuchten parameters; $\mathrm{K}_{\mathrm{S}}=$ saturated hydraulic conductivity.

\begin{tabular}{|c|c|c|c|c|c|c|c|c|}
\hline \multicolumn{9}{|c|}{ Red Latosol } \\
\hline \multirow{2}{*}{ Parameter } & \multicolumn{8}{|c|}{ Depth $(\mathrm{cm})$} \\
\hline & 0-10 & $10-20$ & $20-40$ & $40-60$ & $60-100$ & 100-150 & $150-200$ & $200-600$ \\
\hline $\mathrm{OM}\left(\mathrm{g} \mathrm{kg}^{-1}\right)$ & 33.4 & 29.6 & 22.7 & 16.9 & 11.3 & 6.2 & 7.6 & 7.6 \\
\hline Sand $\left(\mathrm{g} \mathrm{kg}^{-1}\right)$ & 245 & 229 & 212 & 195 & 195 & 195 & 179 & 179 \\
\hline Clay $\left(\mathrm{g} \mathrm{kg}^{-1}\right)$ & 630 & 663 & 697 & 713 & 713 & 713 & 713 & 713 \\
\hline $\mathrm{BD}\left(\mathrm{g} \mathrm{cm}^{-3}\right)$ & 1.02 & 1.11 & 1.14 & 1.11 & 1.10 & 1.15 & 1.14 & 1.14 \\
\hline$\theta_{\mathrm{r}}\left(\mathrm{cm}^{3} \mathrm{~cm}^{-3}\right)$ & 0.22 & 0.23 & 0.23 & 0.24 & 0.25 & 0.26 & 0.28 & 0.28 \\
\hline$\theta_{\mathrm{s}}\left(\mathrm{cm}^{3} \mathrm{~cm}^{-3}\right)$ & 0.61 & 0.58 & 0.59 & 0.57 & 0.57 & 0.56 & 0.56 & 0.56 \\
\hline$\alpha\left(\mathrm{cm}^{-1}\right)$ & 0.081 & 0.064 & 0.059 & 0.045 & 0.027 & 0.025 & 0.022 & 0.022 \\
\hline n (-) & 2 & 1.8 & 1.7 & 1.7 & 2.0 & 1.8 & 1.9 & 1.9 \\
\hline$\lambda(-)$ & 0.5 & 0.5 & 0.5 & 0.5 & 0.5 & 0.5 & 0.5 & 0.5 \\
\hline$\underline{\mathrm{K}}_{\mathrm{S}}\left(\mathrm{m}\right.$ day $\left.^{-1}\right)$ & 7.34 & 3.64 & 2.77 & 2.27 & 1.21 & 2.03 & 0.79 & 0.79 \\
\hline \multicolumn{9}{|c|}{ Red-Yellow Argisol } \\
\hline \multirow{2}{*}{ Parameter } & \multicolumn{8}{|c|}{ Depth (cm) } \\
\hline & $0-10$ & $10-20$ & $20-40$ & $40-60$ & $60-100$ & $100-150$ & $150-200$ & $200-600$ \\
\hline $\mathrm{OM}\left(\mathrm{g} \mathrm{kg}^{-1}\right)$ & 17.5 & 16.5 & 13.8 & 11.0 & 6.9 & 5.2 & 3.8 & 3.8 \\
\hline Sand $\left(\mathrm{g} \mathrm{kg}^{-1}\right)$ & 743 & 743 & 726 & 710 & 693 & 677 & 660 & 660 \\
\hline Clay $\left(\mathrm{g} \mathrm{kg}^{-1}\right)$ & 213 & 230 & 230 & 247 & 263 & 263 & 280 & 280 \\
\hline $\mathrm{BD}\left(\mathrm{g} \mathrm{cm}^{-3}\right)$ & 1.42 & 1.51 & 1.49 & 1.46 & 1.41 & 1.46 & 1.46 & 1.46 \\
\hline$\theta_{\mathrm{r}}\left(\mathrm{cm}^{3} \mathrm{~cm}^{-3}\right)$ & 0.16 & 0.17 & 0.16 & 0.15 & 0.15 & 0.15 & 0.16 & 0.16 \\
\hline$\theta_{\mathrm{S}}\left(\mathrm{cm}^{3} \mathrm{~cm}^{-3}\right)$ & 0.42 & 0.39 & 0.41 & 0.41 & 0.42 & 0.40 & 0.40 & 0.40 \\
\hline$\alpha\left(\mathrm{cm}^{-1}\right)$ & 0.015 & 0.012 & 0.014 & 0.015 & 0.015 & 0.013 & 0.012 & 0.012 \\
\hline $\mathrm{n}(-)$ & 2.5 & 2.9 & 2.5 & 2.5 & 3.0 & 2.8 & 2.8 & 2.8 \\
\hline$\lambda(-)$ & 0.5 & 0.5 & 0.5 & 0.5 & 0.5 & 0.5 & 0.5 & 0.5 \\
\hline$\underline{\mathrm{K}}_{\mathrm{S}}\left(\mathrm{m}\right.$ day $\left.^{-1}\right)$ & 0.49 & 0.80 & 1.08 & 2.95 & 3.73 & 4.19 & 1.85 & 1.85 \\
\hline \multicolumn{9}{|c|}{ Quartzarenic Neosol } \\
\hline \multirow{2}{*}{ Parameter } & \multicolumn{8}{|c|}{ Depth (cm) } \\
\hline & 0-10 & $10-20$ & $20-40$ & $40-60$ & $60-100$ & 100-150 & $150-200$ & $200-600$ \\
\hline $\mathrm{OM}\left(\mathrm{g} \mathrm{kg}^{-1}\right)$ & 7.4 & 6.4 & 5.1 & 4.7 & 5.4 & 3.7 & 3.7 & 3.7 \\
\hline Sand $\left(\mathrm{g} \mathrm{kg}^{-1}\right)$ & 888 & 869 & 852 & 869 & 888 & 852 & 836 & 836 \\
\hline Clay $\left(\mathrm{g} \mathrm{kg}^{-1}\right)$ & 80 & 97 & 111 & 97 & 97 & 111 & 130 & 130 \\
\hline $\mathrm{BD}\left(\mathrm{g} \mathrm{cm}^{-3}\right)$ & 1.36 & 1.55 & 1.53 & 1.51 & 1.47 & 1.48 & 1.51 & 1.51 \\
\hline$\theta_{\mathrm{r}}\left(\mathrm{cm}^{3} \mathrm{~cm}^{-3}\right)$ & 0.06 & 0.08 & 0.09 & 0.075 & 0.073 & 0.075 & 0.081 & 0.081 \\
\hline$\theta_{\mathrm{S}}\left(\mathrm{cm}^{3} \mathrm{~cm}^{-3}\right)$ & 0.39 & 0.38 & 0.40 & 0.39 & 0.40 & 0.39 & 0.35 & 0.35 \\
\hline$\alpha\left(\mathrm{cm}^{-1}\right)$ & 0.030 & 0.018 & 0.019 & 0.023 & 0.024 & 0.023 & 0.019 & 0.019 \\
\hline $\mathrm{n}(-)$ & 2.5 & 3.2 & 3.2 & 3.0 & 3.0 & 3.0 & 3.0 & 3.0 \\
\hline$\lambda(-)$ & 0.5 & 0.5 & 0.5 & 0.5 & 0.5 & 0.5 & 0.5 & 0.5 \\
\hline$\underline{K}_{S}\left(m\right.$ day $\left.^{-1}\right)$ & 3.75 & 1.63 & 0.80 & 6.98 & 5.77 & 3.34 & 1.70 & 1.70 \\
\hline
\end{tabular}

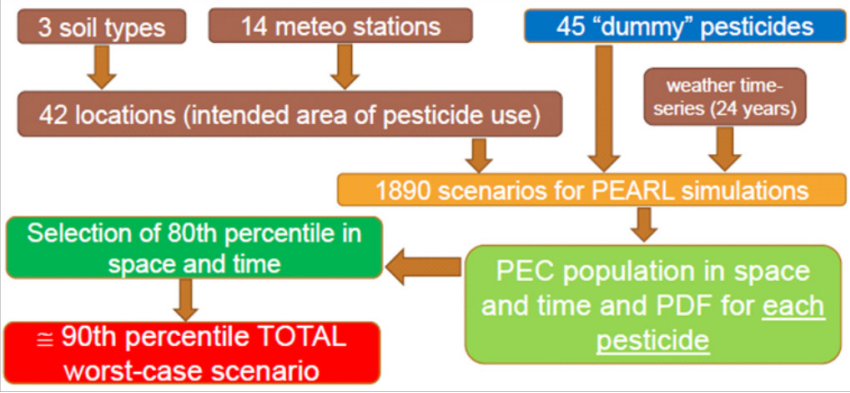

Figure 2. Approach overview to derive soil-climate exposure scenarios and to select worst-case groundwater scenarios. easily identified after ranking all locations and taking the eighth location, which is the 80th percentile for 42 locations. This location corresponds to the spatio-temporal combination of Sidrolândia meteorological station and Quartzarenic Neosol soil class. The PEC value of average annual concentration at 3-m depth that corresponds to 80th percentile in space and time is $49.7 \mu \mathrm{g} \mathrm{L}{ }^{-1}$, which is equal to the 90.1th overall percentile (Figure 3). This overall percentile of 90.13th corresponds to an overall risk exceedance of about $10 \%$ in the intended area of pesticide use. Thus, by using this approach, we can easily derive the overall risk exceedance of a pesticide in the procedure of environmental risk assessment. The PEC value of $49.7 \mu \mathrm{g} \mathrm{L}^{-1}$ (90.1th percentile) can be the exposure endpoint 


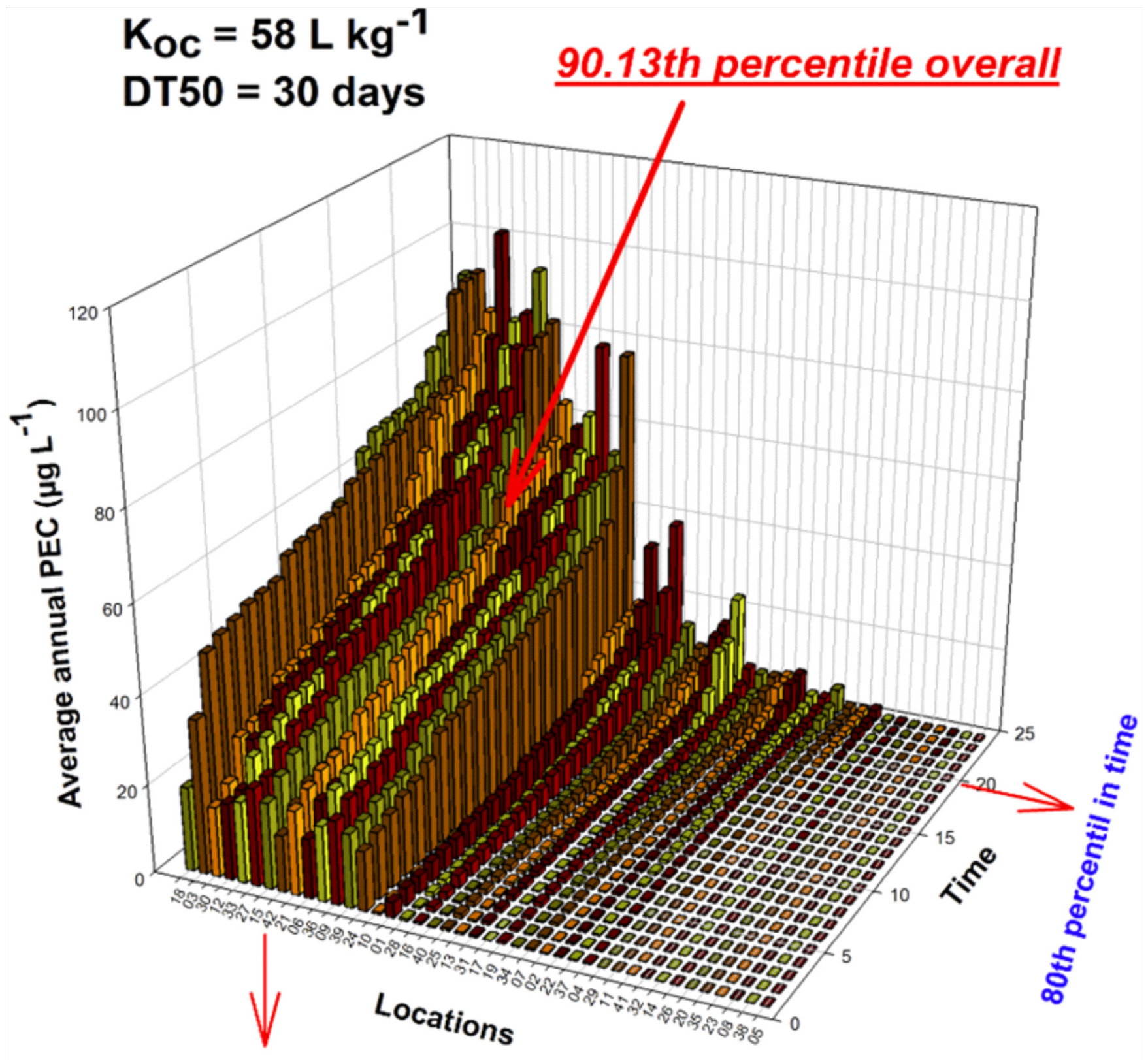

80th percentil in space

Figure 3.Spatio-temporal distribution of annual average concentrations of a generic pesticide $\left(\mathrm{K}_{\mathrm{OC}}=58 \mathrm{~L} \mathrm{~kg}^{-1}\right.$ and DT50 $=30$ days $)$ at 3 -m depth for all 42 locations (combination of 14 meteorological stations and 3 soil types) at Mato Grosso do Sul state during a simulation period of 24 years.

to be latter compared to a regulatory acceptable concentration, for example. So, it is urgent that Brazilian authorities define exposure endpoints at different environmental compartments (i.e. soil, groundwater, surface water etc) to make feasible the implementation of ERA of pesticides in Brazil. More recently, Cervi \&Poleto (2018) pointed out the urgent need for a detailed guidance on ERA in Brazil to fully implement this framework.

The PEC population of average annual concentration at 5 -m depth for a less persistent and more mobile pesticide (i.e DT50 of 3 days and $\mathrm{K}_{\mathrm{OC}}$ of $5.8 \mathrm{~L} \mathrm{~kg}^{-1}$ ) is shown in Figure 4. PEC values for this population ranged from 0 to $50.6 \mu \mathrm{g}$ $\mathrm{L}^{-1}$. Following the same procedure as above, the location that corresponds to 80th in space after being ranked is the spatiotemporal combination of Nova Andradina meteorological station and Quartzarenic Neosol soil class. The PEC value of average annual concentration at $5-\mathrm{m}$ depth that corresponds to 80th percentile in space and time is $9.7 \mu \mathrm{g} \mathrm{L}^{-1}$, which is equal to the 91.2 th overall percentile (Figure 4). This overall percentile of 91.2 th corresponds to an overall risk exceedance of about $9 \%$ in the intended area of pesticide use.

Based on the two pesticides with contrasting mobility and persistence given as examples to illustrate the approach, we conclude that worst-case groundwater scenarios are locations 42 (Sidrolândia meteorological station and Quartzarenic Neosol) for 3-m depth and 30 (Nova Andradina meteorological station and Quartzarenic Neosol) for 5-m depth (Figures 3 and 4). These results showthat Quartzarenic Neosol soil class were selected to represent worst-case groundwater exposure 


\section{$\mathrm{K}_{\mathrm{oc}}=5.8 \mathrm{~L} \mathrm{~kg}^{-1}$ \\ DT50 $=3$ days $\quad$ 91.12th percentile overall}

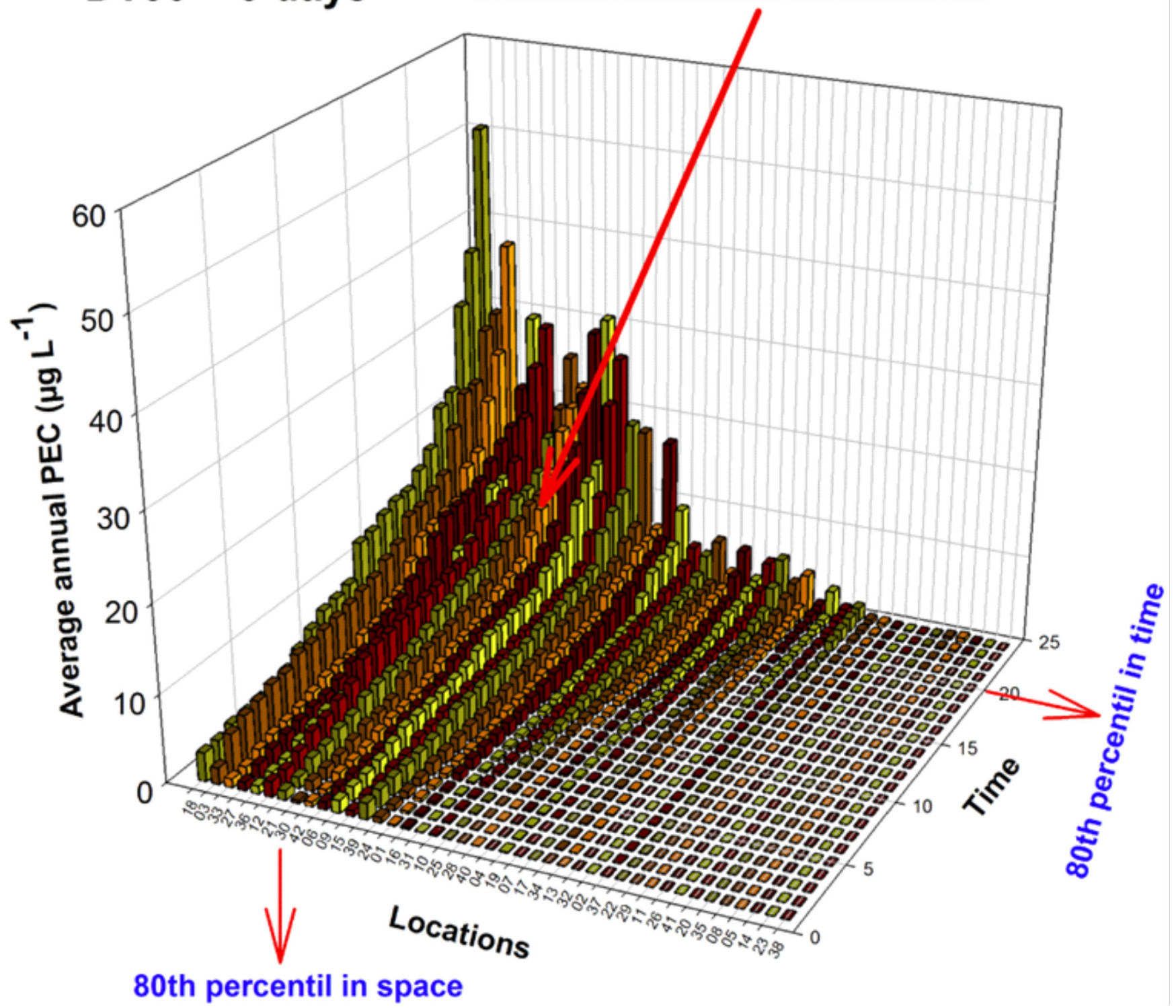

Figure 4. Spatio-temporal distribution of annual average concentrations of a generic pesticide $\left(\mathrm{K}_{\mathrm{OC}}=5.8 \mathrm{~L} \mathrm{~kg}^{-1}\right.$ and DT50 $=3$ days $)$ at 5 -m depth for all 42 locations (combination of 14 meteorological stations and 3 soil types) at Mato Grosso do Sul state during a simulation period of 24 years.

scenarios for both depths. These findings would be expected as Quartzarenic Neosol are well-drained soils, exhibit a high hydraulic conductivity and low water holding capacity (Sartori et al., 2005), which are important soil characteristics that enhance leaching of pesticides to groundwater (Mendes et al., 2016). Mingotiet al. (2016) also concluded that Quartzarenic Neosol is one of the most vulnerable soil class to pesticide leaching in the Cerrado biome.

The main advantage of this approach is to derive the overall percentile of a PEC population given pre-defined spatio-temporal percentiles (i.e. pre-defined risk exceedance values at spatial and temporal dimensions). For this example, we considered an equal risk exceedance of $20 \%$ for both dimensions. In order to check if the overall percentiles for all 45 "dummy" pesticides would be close to what would be expected of 90th percentile, the descriptive statistics of overall percentile populations are shown in Table 4. The average of 45 overall percentiles for annual average concentrations at 3ad 5-m depths were $90.5( \pm 0.9)$ and $90.9( \pm 0.4)$, respectively. These average values are very close to what would be expected of 90th overall percentile, suggesting this approach can guarantee a pre-defined overall percentile once defined by the regulatory authorities. Overall percentiles ranged from 74.9 to 94.1 th for $3-\mathrm{m}$ and from 86.9 to 93.5 th for $5-\mathrm{m}$ depth. The minimum value of 74.9 th for $3-\mathrm{m}$ depth deviates considerably from 90th, but did occur for only one pesticide. However, this shows the importance to check the overall percentile before the definition of the worst-case scenario. 
Table 4. Descriptive statistics of the overall percentile populations of the annual average concentrations at 3 and 5-m depth for all 45 "dummy" pesticides ( 15 pesticides $\mathrm{x} 3$ application dates).

\begin{tabular}{lcc}
\hline \multirow{2}{*}{ Descriptive statistics } & \multicolumn{2}{c}{ Depth } \\
\cline { 2 - 3 } & $\mathbf{3 ~ \mathbf { ~ m }}$ & $\mathbf{5 ~ \mathbf { ~ m }}$ \\
\hline Average & 90.5 & 90.9 \\
Standard error & 0.9 & 0.4 \\
Median & 91.4 & 90.7 \\
Minimum value & 74.9 & 86.9 \\
Maximum value & 94.1 & 93.5 \\
\hline
\end{tabular}

It is important to point out some assumptions in this work, mainly due to data unavailability or lack of detail (i.e. not appropriate scale). These assumptions were: i) equal weight to all soil-climate combinations in the definition of worst-case scenarios (and not attributing different weights based on their representative area); ii) only three soil types; iii) considering some unrealistic soil-climate combinations (see Table 2) that might not occur in the intended area of pesticide use. Thus, we cannot preclude that these assumptions may have led to simplifications and, thus, future work has to be done to investigate the consequences.It would be desirable that this decision to simplify or not and the consequences in the ERA of pesticides could be agreed by regulatory authorities, researchers and industry.

\section{CONCLUSIONS}

Our results have shown that this statistically based approach to define worst-case groundwater exposure scenarios considering spatio and temporal variability of meteorological and soil data for the intended area of pesticide use can be easily implemented by the Brazilian authorities. In this casestudy using soil and meteorological data of Mato Grosso do Sul, the resulted worst-case groundwater exposure scenarios included very vulnerable soils to leaching of pesticides.This approach tends to be more close to reality as geoinformation are available in an appropriate scale and resolution. The main advantage of this approach is to guarantee a pre-defined risk exceedance on both dimensions (spatial and temporal) leading to a known overall risk exceedance that should be defined by the regulatory authorities. Therefore, a defensible and clear compromise among authorities and society can be established in the ERA of pesticides.

\section{ACKNOWLEDGMENTS}

We thank the reviewers, in special Dr. Bernhard Jene, for their helpful comments and important suggestions to improve the quality and understanding of the paper. This work was partially supported by the project "Mathematical models applied to the assessment of farming systems' impacts on water resources" (research contract: 01.12.01.001.01.00) at EMBRAPA.

\section{REFERENCES}

AGÊNCIA NACIONAL DE ÁGUAS (ANA). 2018.HidroWeb: sistemas de informações hidrológicas. Available at: http://www. snirh.gov.br/hidroweb/publico/apresentacao.jsf

ALLEN, R. G., PEREIRA, L. S., RAES, D., SMITH, M. 1998. Crop evapotranspiration: Guidelines for computing crop water requirements. Rome: FAO, 1998. 300 p. (FAO - Irrigation and Drainage Paper, 56).

BACH, M., DIESNER, M., GROßMANN, D., GUERNICHE, D., HOMMEN, U., KLEIN, M., KUBIAK, R., MÜLLER, A., PREUSS, T.G., PRIEGNITZ, J., REICHENBERGER, S., THOMAS, K., TRAPP, M. 2016. Pest Manag. Sci., 73:852-861. https://onlinelibrary.wiley.com/doi/pdf/10.1002/ps.4519

BOESTEN, J. J. T. I. 1991. Sensitivity analysis of a mathematical model for pesticide leaching to groundwater. Pestic. Sci. 31:375-388.

CERVI, E. C., POLETO, C. 2018. Ecological risk assessment of freshwater sediments in Brazil. Rev. Bras. Ciênc. Amb. 48:120. https://www.yumpu.com/pt/document/fullscreen/61892395/ edicao-48-rbciamb

DUBUS, I. G., BROWN, C. D. 2002. Sensitivity and first-step uncertainty analysis for the preferential flow model MACRO. J. Environ. Qual. 31:227-240.

FOCUS, 2000. FOCUS groundwater scenarios in the EU review of active substances. Report of the FOCUS Groundwater Scenarios Workgroup, EC Document Reference Sanco/321/2000 rev.2, $202 \mathrm{pp}$.

HIRATA, R., BASTOS, C., ROCHA, G.1997. Mapeamento da vulnerabilidade e risco de poluição das águas subterrâneas no Estado de São Paulo. IG/CETESB/DAEE, Secretaria do Meio Ambiente do Estado de São Paulo (Série Documentos). 2 vol.

MATO GROSSO DO SUL. 1990. Secretaria de Planejamento e Coordenação Geral. Atlas Multirreferencial. Campo Grande, 28p.

MENDES, K. F., INOUE, M. H., GOULART, M. O., PIMPINATO, R. F., TORNISIELO, V. L. 2016. Water Air Soil Pollut. 227:268. https://doi.org/10.1007/s11270-016-2954-4

MINGOTI, R., SPADOTTO, C. A., MORAES, D.A.C. 2016. Suscetibilidade à contaminação da água subterrânea em função de propriedades dos solos no Cerrado brasileiro. Pesq.Agropec.Bras., 51(9):1252-1260.http://www.scielo.br/scielo.php?pid=S0100204X2016000901252\&script $=$ sci_abstract\&tlng $=\mathrm{pt}$

USEPA(United States Environmental Protection Agency). 2015. Implementation of the Pesticide Root Zone Model Groundwater (PRZM-GW)for use in EPA's pesticide exposureassessments. Washington - DC. 49p. http://www.epa.gov/ sites/production/ files/2015-11/documents/attachment_1___implementation_ report_of_przm-gw_final.pdf

REBELO, R. M., CALDAS, E. D. 2014. Avaliação de risco ambiental de ambientes aquáticos afetados pelo uso de agrotóxicos. Quim. Nova, 37(7):1199-1208. http://dx.doi.org/10.5935/01004042.20140165

SARTORI, A., LOMBARDI NETO, F., GENOVEZ, A. M. 2005. Classificação hidrológica de solos brasileiros para estimativa da chuva excedente com o Método do Serviço de Conservação do Solo dos Estados Unidos. Parte 1: Classificação. Rev. Bras. Rec. Hídricos, 10(4):05/18. https://www.abrh.org.br/SGCv3/index. php?PUB $=1 \& I D=26$

SCORZA JÚNIOR, R.P., SILVA, J.P. 2007. Potencial de contaminação da água subterrânea por pesticidas na bacia do Rio Dourados, MS. Pesticidas: Rev. Ecotoxicol. e Meio Ambiente., 17:87-106. http://revistas.ufpr.br/pesticidas/article/view/10666

STACKHOUSE, P.W., WESTBERG, D., HOELL, J.M., CHANDLER, W.S., ZHANG, T. 2015. Prediction of Worldwide Energy Resource (POWER) - AgroclimatologyMetodology - 
(1.0 Latitude by 1.0 Longitude Spatial Resolution). Technical Report of NASA. Langley Research Center. 46p.

VAN DEN BERG, F., TIKTAK, A., BOESTEN, J. J. T. I., VAN DER LINDEN, A. M. A. (2016). PEARL model for pesticide behavior and emissions in soil-plant systems: description of processes. Wot-technical report 61. 134p.

VAN GENUCHTEN, M. Th., LEIJ, F. J., YATES, S. R. The RETC code for quantifying the hydraulic functions of unsaturated soils.
Riverside: US Salinity Laboratory, 1991. 93p.

VANDERBORGHT, J., TIKTAK, A., BOESTEN, J.J.T.I., VEREECKEN, H. 2011. Effect of pesticide fate parameters and their uncertainty on the selection of "worst-case" scenarios of pesticide leaching to groundwater. Pest Manag. Sci., (67): 294306.https://onlinelibrary.wiley.com/doi/abs/10.1002/ps.2066 